\title{
The influence of internal audit and internal control toward fraud prevention
}

Bregitta Roemkenya Madolidi Handoyo ${ }^{1 *}$, Bunga Indah Bayunitri ${ }^{2}$

Accounting Department, Widyatama University, Bandung, Indonesia ${ }^{1,2}$ bregitta.roemkenya@widyatama.co.id $^{1 *}$, pmb@widyatama.ac.id ${ }^{2}$

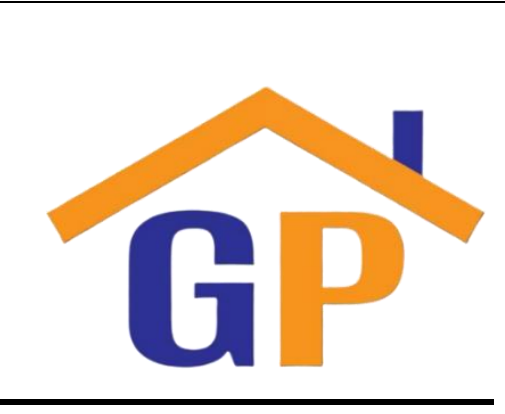

Article History

Received on 20 July 2020

$1^{\text {st }}$ Revision on 11 August 2020

$2^{\text {nd }}$ Revision on 14 September 2020

$3^{\text {rd }}$ Revision on 11 October 2020

Accepted on 12 October 2020

\begin{abstract}
Purpose: This study aimed to determine whether there is an influence of internal audit and internal control on fraud prevention at PT Pos Indonesia (Persero) Bandung.

Research methodology: This study used the verification method, the sampling technique used in this study was a combination of non-probability with a saturated sampling technique. The sample in this study were employees at PT Pos Indonesia (Persero) Bandung City, amounting to 91 people. The Program used in analyzing data was Statistical Package for Social Sciences (SPSS) Ver25.00.

Results: The results showed that internal audit and internal control influence the prevention of fraud in PT Pos Indonesia (Persero) Bandung. In addition, the magnitude of the influence of internal audit and control in contributing to the prevention of fraud by $68.8 \%$.

Limitations: The study was only conducted at PT Pos Indonesia (Persero), Bandung City.

Contribution: This research is expected to be able to provide input for PT Pos Indonesia (Persero) Bandung City which is aimed at improving improvements in minimizing and preventing fraud, and can be used as additional information for related parties.

Keywords: Internal audit, Internal control, Fraud prevention

How to cite: Handoyo, B. R. M., \& Bayunitri, B. I. (2021). The influence of internal audit and internal control toward fraud prevention. International Journal of Financial, Accounting, and Management, 3(1), 45-64.
\end{abstract}

\section{Introduction}

Basically, every activity in the company will not be separated from the risk. Every organizational activity has uncertainty that is identical to risk, including fraud (Karyono, 2013:1). Fraud can be termed as fraud that contains meaning and irregularities and illegal acts, which is done intentionally for a specific purpose, such as deceiving or giving misleading images to other parties. People can do this both from within and from outside the organization. Fraud is designed to take advantage of opportunities that are not honest, which directly or indirectly harm other parties (Karyono, 2013:4). In Indonesia alone, fraud cases still frequently occur in various companies, both private companies or state-owned/regional companies. The 2016 Global Association of Certified Fraud Examiners (ACFE) results show that each year an average of 5\% of organizational revenues in Indonesia are victims of fraud (ACFE Indonesian Chapter, 2017).

Fraud prevention is eliminating opportunities or opportunities to commit fraud by developing and implementing risk management (specifically fraud risk management), internal control and honest corporate governance (Priantara, 2013:184). One way to minimize fraud in the company is important for companies to improve the effectiveness of the internal audit. This internal audit helps the organization achieve its goals by taking a systematic and disciplined approach to assess and improve risk management, control, and governance processes (Redding et al., 2013:2). The internal audit 
function is a function of free appraisal within an organization to review or study and assess the company's activities to provide suggestions to management so that their responsibilities can be carried out effectively (Tugiman, 2014:11). Internal auditors as the most appropriate agent to realize internal control, risk management and good corporate governance, which will undoubtedly add value to resources and the company (Kumaat, 2014:35).

Risks faced by the company include integrity risk, namely the risk of fraud by management or company employees, illegal actions, or other irregularities that can reduce the good name/reputation of the company in the business world or can reduce the company's ability to manage internal audit is an autonomous activity, objective viewpoints, and consultation meant to add value and enhance organizational works. This internal audit helps the organization achieve its objectives by taking a methodical and disciplined appearance to evaluate and enhance the effectiveness of risk management, control, and governance processes (Redding et al., 2013:2). Internal audits intend to help companies perform adequate controls by evaluating their effectiveness and efficiency and encourage continuous enhancement (Sawyer et al., 2014:55). The risk of fraud requires the internal auditor to develop preventive measures to prevent fraud (Amrizal, 2014:11).

In addition to internal auditing, one factor of fraud in the company is caused by weak internal control (ACFE, 2017). Internal control is a process composed, performed, and controlled by those charged with governance, management, and other employees to provide sufficient confidence regarding the fulfillment of an entity's objectives correlating to the reliability of financial statements, efficiency and effectiveness of operations, and compliance with laws (Agoes, 2017:162).

The paramount prevention of fraud is to establish an internal control system in every movement of the organization. In order to effectively inhibit fraud, internal control must be competent in the design of its control structure and sound practices in its implementation (Karyono, 2013:47). The relationship between internal control and fraud problems in a company is very related. Fraud is always a difficult issue. A good internal control system aims to ensure that organizational activities are effective and efficient (Tugiman, 2014:12). A comprehensive internal control system, implemented thoroughly and regularly monitoring the activities of an organization, is an important step to safeguard and detect the risk of loss caused by fraud in the financial sector. Internal control is very important in detecting financial fraud that is at the risk of harming the company (Susanto, 2014:93). Implementation of internal control can at least reduce management collusion regarding fraud (Natasya et al., 2017).

Information quoted from the article shows that PT Pos Indonesia still commits corruption in connection with the procurement of Portable Data Terminal (PDT), namely regarding corruption cases related to the cost of sending Social Protection Cards (KPS) and incompatible specifications of the equipment provided by the agreement in the procurement contract. The case of making the country suffer losses due to the procurement of funds obtained from the Ministry of State-Owned Enterprises (BUMN) (Rahman, 2016). Other information shows that there is still allegations of corruption committed by PT Pos Indonesia related to the provision of tantiem or bonuses to the directors and commissioners of PT Pos Indonesia in 2017 by selling assets in the form of shares in Mandiri Taspen Pos Bank. The granting of bonuses when companies suffer losses can be categorized as detrimental to the state leading to corruption (Movanita, 2017). Therefore we need an activity to prevent fraud.

Other information quoted from the 2017 national Kompas article, Boyamin Saiman, as the Coordinator of the Indonesian Anti-Corruption Society, stated that PT Pos Indonesia had suspected corruption. Boyamin Saiman suspected that there were irregularities in giving bonuses to the directors and commissioners of PT Pos Indonesia in 2017, even though the company was at a loss. PT Pos Indonesia is suspected of attempting to manipulate the books so that it appears as if it is experiencing profits by selling assets in the form of shares in Bank Mandiri Taspen Pos. PT Pos Indonesia gave Rp. $5,359,000,000$ to the company's Directors and Commissioners in 2017. In the same year, PT Pos Indonesia was declared to be losing money based on the company's 2017 balance sheet. Boyamin Saiman also stated that giving bonuses when the company loses money can be categorized as causing

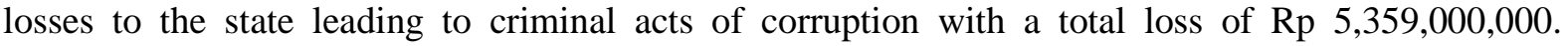


Moreover, the bonus was given after selling assets in the form of shares in Bank Mantap amounting to Rp 324.61 billion. Of this amount, IDR 200 billion was included as revenue. In addition, Boyamin Saiman considered the sales figures too cheap. Along with the report, Boyamin attached evidence in the form of PT Pos Indonesia's profit and loss report to a list of tantiem payments to company directors and commissioners from the Attorney General's Office (Movanita, 2017).

Several previous studies relating to this study have been conducted by Maliawan et al. (2017). The results of his research indicate that internal audit and the effectiveness of internal control affect the prevention of fraud. Research conducted by Suginam (2017) shows that internal audit and internal control have an effect on fraud prevention. In addition, research conducted by Wijaya and Nugraha (2017), the results of his study showed that internal control and internal audit affect fraud. Based on the results above, the researcher is interested in further researching the effect of internal audit and internal control on fraud prevention at PT Pos Indonesia (Persero) Bandung.

\section{Literature review and hypotheses development}

\subsection{Internal audit}

Internal auditing is an activity designed to increase value and improve organizational performance. This activity can help achieve an organization's goals by conducting a methodical and disciplined approach to evaluating and improving risk management, control, and governance processes through activities in the form of independent and objective consultation and assurance (Redding et al., 2013:2). The internal audit function is a function of free appraisal within an organization to review or study and assess the company's activities to provide suggestions to management so that their responsibilities can be carried out effectively (Tugiman, 2014:11). Internal audit aims to assist all company leaders (management) in carrying out their responsibilities by analyzing assessments, suggestions, and comments on the activities they inspect (Agoes, 2017:222). The scope of the internal inspection must include testing and evaluation of the competence and effectiveness of the organization's internal control system and the quality of the implementation of the responsibilities given, including the reliability of the information, compliance with legal policies and procedures, protection of assets, use of resources economically and efficiently and achieving goals (Tugiman, 2014:17). According to The Institute of Internal Auditors (IIA) in Redding et al. (2013:19) states that internal audit measurements based on performance standards consist of the following:

1. Manage internal audit activities

The head of internal audit must manage internal audit activities effectively to ensure that these activities add value to the organization.

a. Planning

The head of internal audit must prepare a risk-based plan (risk-based plan) to set priorities for the activities of the internal audit activity according to the organization's objectives.

b. Communication and Approval

The internal audit commander communicates the designed internal audit movement and reserve obligations, including critical interim replacements, superior supervision, and the board for evaluation and approval. The head of internal audit must likewise communicate the consequence of resource restrictions.

c. Resource Management

The role of the chief audit executive is to guarantee that possible audit resources can be used appropriately and adequately to fulfill the agreed project.

d. Policies and Procedures

The head of the internal audit must set strategies and schemes to direct/guide internal audit activities.

e. Coordination

The head of internal audit must share information and coordinate its activities with all other external and internal insurance and insurance service providers, to ensure that the scope of assignment is appropriate and minimize duplication of activities.

f. Report to Senior Management and the Board 
The head of internal audit must periodically report the objectives, authorities, responsibilities, and performance of the internal audit activity to his plan. The report must also include significant risks faced, problems with control, risks of fraud, governance problems, and other elements ordered or requested by senior executives and the jury.

g. External Service Providers and Organizational Responsibility for Internal Audit

Suppose there are external service providers who provide internal audit services in the organization's internal audit activities. In that case, the service provider must provide an understanding that the organization has the responsibility to maintain effective internal audit activities.

2. The nature of the work

Internal audit activities must estimate and commit to enhancing governance, risk management, and control methods using a well-organized and orderly approach.

a. Governance

Internal audit activities must estimate and provide suggestions that are appropriate for enhancing the governance rule in achieving the following intentions:

1) Development of ethics and values that are appropriate in the organization.

2) Ensuring that the management and accountability of organizational performance have been effective.

3) Transferring risk and control knowledge in relevant fields within the group.

4) Coordinate activities and communicate information effectively between the Board of Trustees, external and internal auditors, and management.

b. Risk management

Internal audit activities include assessing the effectiveness and contributing to improving the risk management process. The results of the evaluation of the effectiveness of the risk management process constitute an opinion based on the auditor's evaluation that:

1) The objectives of the organization have supported and are related to the mission of the organization;

2) Significant uncertainties have been identified and assessed;

3) The appropriate risk response has been chosen and in accordance with the organization's risk appetite.

4) Proper erudition about risks has been obtained and conveyed promptly to all organizational units, enabling workers, Management, and the Board to bring out their responsibilities.

c. Control

Internal audit activities must help the organization maintain effective control by evaluating its efficiency and effectiveness and encourage sustainable development.

3. Assignment planning

Internal auditors must prepare and document a plan for each assignment that includes the objectives of the assignment, the scope, time, and allocation of resources.

a. Purpose of Assignment

A goal must be set for each assignment.

1) Internal auditors' require to carry a preliminary estimation of the prospects relevant to the activity being evaluated. The purpose of the appointment must display the results of the evaluation.

2) Internal auditors must analyze the significant probability of vital errors, deception, disobedience, and separate exposures when composing assignment aspirations.

3) In order to evaluate governance, risk management, and control, adequate criteria are needed. The internal auditors have to ascertain whether management and/or the board have implemented sufficient criteria to ascertain whether the objectives set out have been achieved. Furthermore, these criteria will be used by internal auditors in evaluating. However, if this is not sufficient, internal auditors must work closely with management and/or the board to establish appropriate evaluation criteria. 
4) The purpose of consulting assignments must be directed to the governance, risk and control processes, in accordance with agreements made with clients.

5) Consultation assignment objectives must be consistent with organizational values, strategies and goals.

b. Scope of assignment

The assigned scope of assignment must be sufficient to achieve the objectives of the assignment.

c. Assignment of Resource Assignments

Internal auditors must arrange suitable and sufficient resources to accomplish the assignment's objectives, based on evaluating each assignment's characteristics and level of complexity, time restrictions, and supplies that can be used.

d. Assignment Work Program

Internal auditors must develop and report work plans to accomplish the intentions of the assignment.

4. Implementation of assignments

In order to achieve the purpose of the assignment, it is the job of the internal auditor to identify, analyze, evaluate, and adequate document information.

a. Identifying Information

Internal auditors are tasked with finding adequate, reliable, relevant, and useful information in achieving the assignment's purpose.

b. Analysis and Evaluation

In analyzing and evaluating, internal auditors must make appropriate conclusions and provide accurate assignment results.

c. Documenting Information

Internal auditors must document relevant information to support the conclusions and results of the assignment.

d. Supervision of Assignments

Each assignment must be supervised appropriately to ensure that goals are achieved, quality is guaranteed, and staff are educated.

5. Communication of assignment results

It is the internal auditors' duty to report the results of their assignments.

a. Communication Criteria

Communication must comprehend the assignment's purposes and field and outcomes, advice, and follow-up plans.

b. Communication Quality

The information presented must be accurate, objective, transparent, constructive, concise yet complete, and up-to-date.

c. Use of the phrase "Implemented in accordance with International Standards for Internal Audit Professional Practice."

Internal auditors may only report that the insurance program results and quality improvement are carried out following the International Standards of Professional Practice in Internal Audit only when it is in accordance with the facts in the field.

d. Submission of Assignment Results

The head of the internal audit must report the outcomes of the assignment to interested participants.

e. General Opinion

If there is a general opinion, the opinion must pay attention to senior management's expectations and the committee and other stakeholders. It must be sustained by adequate, authentic, appropriate, and useful data.

6. Monitoring progress 
The head of internal audit must establish and maintain a system for monitoring dispositions on the assignments' results communicated to executives. The head of internal audit must set a follow-up method to control and guarantee that senior executives have implemented corrective operations adequately or accept the risk of not carrying out corrective actions. Internal audit activity must control the disposition of the consulting assignment's results to monitor the client's corrective actions in accordance with the results of the consultancy assignment agreement.

7. Communication on risk acceptance

The head of internal audit concludes that executives have assumed risks that cannot be borne by the organization. The head of internal audit must discuss this issue with senior executives. If the internal audit head believes that the problem has not been resolved, the internal audit head must report the subject to the supervisory committee.

\subsection{Internal control}

Internal control is a method meant to provide appropriate assurance regarding the achievement of objectives related to progress, reporting, and compliance. This process is influenced by the board of directors, management, and other entity personnel (Redding et al., 2013:6). According to Tuanakotta (2015:94) states that the objectives of internal control are as follows:

1. Strategic objectives, with the main objectives that support the entity's mission.

2. The purpose of financial reporting, so that financial statements are free from material misstatements in a timely and effective manner

3. Operational objectives, whereby controls secure the entity's operations, known as operational controls

4. The purpose of compliance with laws and statutory provisions. Internal commands appropriate for an audit are controls for financial reporting, particularly those relating to the entity's purpose making economic reports for external purposes.

According to the Committee of Sponsoring Organization of the Treadway Commission (COSO) in Redding et al. (2013:9) states that the internal control component consists of:

1. Control environment

Consists of steps, methods, and systems that indicate top management, directors, and overall entity owners concerning internal instrument and their relevance to the entity. There are essential instrument subcomponents, namely:

a. Integrity and Ethical Values

Integrity and ethical values are products of the entity's decent and behavioral measures and how those standards are taught and enforced in usage. This sub-component includes management efforts to eliminate or decrease impulses and lures that sway employees to commit dishonest, illegal, or unethical actions. This also includes communicating entity preferences and behavior standards to workers through policy charges, principles of conduct, and examples.

b. Commitment to Competence

The knowledge and skills needed to complete a task or job are called competencies. Its commitments include management thoughtfulness about competence for a demanding job and how that level translates into the skills and knowledge required.

c. Management Operations Philosophy and Style

Management is responsible for giving clear signals to employees about the importance of internal control, whether the manager will take a significant risk or avoid it.

d. Organizational structure

The organizational structure of the substance determines the limits of charge and existing authority.

e. Human Resources Policy and Practice

The most important aspect of internal control is personal. Because competent and trusted personnel can control internal control, including building adequate controls, methods for 
appointing, evaluating, training, promoting, and compensating personnel. While an incompetent person will only break the system, there is much control in place.

\section{Risk assessment}

The company goals' achievement is potentially threatened by some risks faced by the company itself. Therefore, every risk, including the internal and external risks must be assessed. According to COSO, all company is facing various kind of risks originating from within and outside. Further, the risk is the likelihood of an event emerging and affecting the objectives' or the patients' achievement.

3. Control activities

Control activities are procedures, steps, and policies used to ensure the crucial action to solve, prevent or deal with risks to help the company achieve the company goals. Control activities consist of some actions done by the company management, boards, and other parties. This action is done to increase the company's level of success in reaching their goal and reducing any potential risk. Therefore, the control activities must be carried out at every level in the company. In addition to separating duties or obligations, there are several control activities implemented in a sound internal control system, namely:

Documentation (comprehensive and strict)

b. Independent verification along with reconciliation

c. Control activities through physical access

d. Controlling activities application (input; process; output)

e. Review of performance and follow-up

f. Authorization (approval)

g. Access to control activities

4. Information and communication

In order to run a business effectively, every relevant, timely, and accurate information should be available for access by everyone in the organization at every level. Meanwhile, the highquality information should be spread and communicated appropriately. The information must be available for certain parties to support operational achievement, compliance, as well as for reporting purpose. In addition, good communication should be applied widely in terms of achievement, the responsibilities of each individual or group, and other important matters

\section{Monitoring}

Monitoring activities are the internal control related to the quality assessment. This activity is also defined as the ongoing or periodic activity to determine the controlling process as expected by the management. The information for the monitoring process is gained from many sources, such as the reports from an internal auditor, the studies of existing internal control, and the feedback from operational personnel. Implementing a multilevel approach will increase the effectiveness of the monitoring activities. The first monitoring level is including the daily activities done by the company's management. The second level is a separate evaluation for internal control done by the management to ensure the identification and resolution of deficiencies in a timely manner. Then, the third level of monitoring activity is the independent assessment, for instance, doing the internal audit function in order to ensure controlling effectiveness from the accuracy and reliability of the management's assessment. Afterward, it can be concluded that the monitoring activities occur in every internal control's components.

\subsection{Fraud prevention}

The word fraud contains meaning as well as irregularities and illegal acts, which are done intentionally for certain purposes such as deceive or providing a misleading image to other parties, whether good people do it from the outside or within the company. Fraud is designed to take 
advantage of opportunities that are not honest, which directly or indirectly harm other parties (Karyono, 2013:4). According to Arens et al. (2014:340) states that there are three factors a person commits fraud known as a fraud triangle, namely as follows:

1. Pressure

Economic pressure is one of the factors that drives a person to commit acts of fraud. This factor comes from the individual of the offender where he feels that the pressures of life are so heavy forcing the offender to commit fraud for his personal gain. This usually happens because the welfare guarantee offered by the company or organization where he works is lacking or a completely luxurious lifestyle so that the perpetrator constantly feels inadequate. However, the pressure can also come from the environment in which he works, such as an unpleasant work environment. Employees feel they are not treated fairly. There is an unfair employee recruitment process.

2. Opportunity

The opportunity factor comes from the outside of any individual, namely from the organization as victims of fraud. There are chances or possibilities to commit fraud in all position. With his position, the offender feels he has the opportunity to take advantage. Coupled with a control system from an inadequate organization.

3. Rationalization

The perpetrator feels he has strong reasons for justifying what he is doing and influencing the other party to approve what he is doing.

Fraud prevention eliminates opportunities to commit fraud by developing and implementing risk management (especially fraud risk management), internal control and honest corporate governance (Priantara, 2013:184). According to Priantara (2013:196) states that fraud that may occur must be prevented, among others, by the following methods:

1. Build a good internal control structure

The more a company develops, the task of management to control the company's operations becomes increasingly heavy. So that the goals set by top management can be achieved, the security of company assets is guaranteed, so that the management needs to establish a good as well as effective internal control structure to prevent fraud can be carried out efficiently and effectively.

2. Making the control activities effective

Making effective control activities can be done by reviewing employee performance, processing information to become information that has accuracy and completeness, physical control of assets by adequate safeguarding facilities that are protected from access to assets, and segregation of duties is useful to give responsibilities to people different in order to avoid double duty and authority.

3. Improve organizational culture

Improving organizational culture is done by implementing the principles of the GCG (Good Corporate Governance) principle that are interrelated to encourage the organization resources' performance to work efficiently.

4. Making the internal audit function effective

Although the internal auditor cannot guarantee that fraud will not occur, he must use the proficiency of his position carefully so that fraud detection is expected and be able to provide useful suggestions to management to prevent fraud.

\subsection{Relationship of internal audit on fraud prevention}

One way to prevent and minimize fraud is to improve internal audit. Internal audits aim to assist the organizations in implementing the significant controls by examining the level of efficiency and effctiveness and encouraging constant improvement. (Sawyer et al., 2014:55). Internal auditors as the most appropriate agent to realize internal control, risk management and good corporate governance, which will certainly add value to resources and the company (Kumaat, 2014:35).

Risks faced by the company include integrity risk, namely the risk of fraud by management or company employees, illegal actions, or other irregularities that can reduce the good name/reputation 
of the company in the business world or can reduce the company's ability to maintain internal audit is a neutral or independent activity, impartial beliefs. Consultation is designed for improving the organizational work by adding some values to it. This internal audit assists the organization to reach their goals by taking a disciplined and systematic approach for improving and evaluating the risk management's control, level of effectiveness, and governance processes (Redding et al, 2013: 2). The task of minimizing and preventing fraud belongs to the internal auditors. These tasks are done by testing the effectiveness and adequacy of the internal controlling system and evaluating the studied potential risks' extention (KOPAI, 2004: 65). The existence of these risks requires internal auditors to develop preventive actions that can minimize fraud (Amrizal, 2014). According to the preceded description, the hypotheses formed are as follows:

$\mathrm{H}_{1}$ : Internal audit influences on fraud prevention.

\subsection{Relationship of internal control on fraud prevention}

Establishing an internal control system for every organization activity is the main point of preventing fraud. Further, implementing this internal control system should be reliable in its control structure design and sound practices to achieve effective fraud prevention (Karyono, 2013:47). The internal control and fraud problems in a company have a close and related relationship. Fraud is always a difficult issue. A good internal control system aims to ensure that organizational activities are effective and efficient (Tugiman, 2014:12).

A comprehensive internal control system implemented thoroughly and regularly monitoring the activities of an organization is an important step to safeguard and detect the risk of losses caused by fraud in the financial sector. Internal control is very important in detecting financial fraud that is at the risk of harming the company (Susanto, 2014:93). Implementation of internal control can at least reduce management collusion regarding fraud (Natasya et al., 2017). Fraud prevention strategies are related to controlling the drivers of fraud by creating conditions that can encourage fraud prevention efforts, so to implement this strategy, internal control must be implemented effectively. Good internal control is a widely used method by many parties to prevent fraud. Therefore it can be stated that a good internal control application will improve fraud prevention as well (Wulandari and Nuryatno, 2018). Based on the description above, the hypotheses formed are as follows:

$\mathrm{H}_{2}$ : Internal control influences on fraud prevention

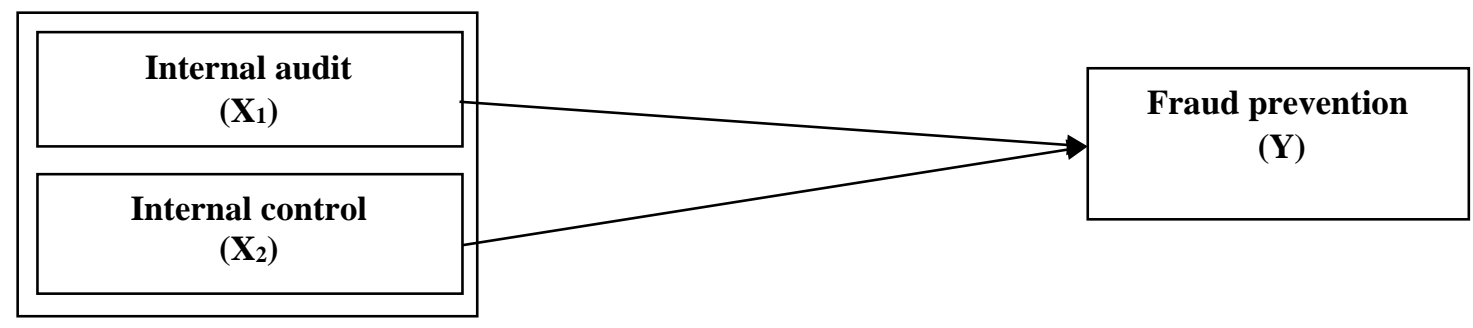

Figure 1. Framework

\section{Research methodology}

This research was using the quantitative research type for analysis. The research methodology used in this study was the verification research method. 91 employees at PT Pos Indonesia (Persero), Bandung City, were taken as the population in this study. Then, this study was also used the nonprobability sampling with the method of saturated sampling. Below will be presented the number of employees from each division at PT Pos Indonesia (Persero) Bandung, as follows:

Table 1. Number of employees in each division at PT Pos Indonesia (Persero) kota Bandung

\begin{tabular}{|c|l|c|}
\hline No & \multicolumn{1}{|c|}{ Division } & $\begin{array}{c}\text { Number of } \\
\text { employees }\end{array}$ \\
\hline 1. & Post master & 1 \\
\hline 2. & Quality control & 10 \\
\hline 3. & Asset & 6 \\
\hline
\end{tabular}




\begin{tabular}{|c|l|c|}
\hline 4. & Branch supervisor & 5 \\
\hline 5. & Financial service & 14 \\
\hline 6. & Human capital & 7 \\
\hline 7. & Mail \& logistic & 33 \\
\hline 8. & Customer care & 15 \\
\hline \multicolumn{2}{|c|}{ Total population } & $\mathbf{9 1}$ \\
\hline
\end{tabular}

Source: PT Pos Indonesia (Persero) Bandung

The types and data source used in this research are the primary data. Data collection methods used in this study are through a questionnaire that is distributed directly to research respondents. The independent variable in this study is internal audit and internal control, while fraud prevention is the dependent variable. The data analysis method applied in this research is multivariate analysis. The multivariate analysis applied in this research is the analysis of multiple linear regression using SPSS Vers.25.00 software.

Below is the questionnaire used in this study:

Table 2. Internal audit variable questionnaire (X1)

\begin{tabular}{|c|c|c|c|c|c|c|}
\hline \multirow{2}{*}{ No } & \multirow{2}{*}{ Questions } & \multicolumn{5}{|c|}{ Alternative answers } \\
\hline & & SA & $\mathbf{A}$ & QA & D & SD \\
\hline \multicolumn{7}{|c|}{ Managing internal audit activities } \\
\hline 1. & $\begin{array}{l}\text { The head of internal audit at PT Pos } \\
\text { Indonesia (Persero) Bandung City } \\
\text { compiles a risk-based plan during the } \\
\text { internal audit implementation }\end{array}$ & & & & & \\
\hline 2. & $\begin{array}{l}\text { The internal audit head at PT Pos } \\
\text { Indonesia (Persero) Bandung City } \\
\text { communicates plans for internal audit } \\
\text { activities and resource needs to the } \\
\text { board and senior management as well. }\end{array}$ & & & & & \\
\hline 3. & $\begin{array}{l}\text { Internal auditor resources at PT Pos } \\
\text { Indonesia (Persero) Bandung City are } \\
\text { appropriate, adequate, and can be used } \\
\text { for the implementation of internal } \\
\text { audits }\end{array}$ & & & & & \\
\hline 4. & $\begin{array}{l}\text { The internal audit head of PT Pos } \\
\text { Indonesia (Persero) Bandung City } \\
\text { establishes policies and procedures for } \\
\text { implementing internal audits }\end{array}$ & & & & & \\
\hline 5. & $\begin{array}{l}\text { The head of the internal audit of PT } \\
\text { Pos Indonesia (Persero) Bandung City } \\
\text { coordinates its activities with all } \\
\text { assurance service providers and } \\
\text { external and internal consultant }\end{array}$ & & & & & \\
\hline 6. & $\begin{array}{l}\text { Reports submitted to senior } \\
\text { management and the board cover } \\
\text { significant risks encountered, control } \\
\text { issues, risk of fraud and governance } \\
\text { issues }\end{array}$ & & & & & \\
\hline 7. & $\begin{array}{l}\text { External service providers who } \\
\text { provide internal audit services must } \\
\text { provide an understanding that the } \\
\text { organization has a responsibility to } \\
\text { maintain an effective internal audit } \\
\text { activity }\end{array}$ & & & & & \\
\hline
\end{tabular}




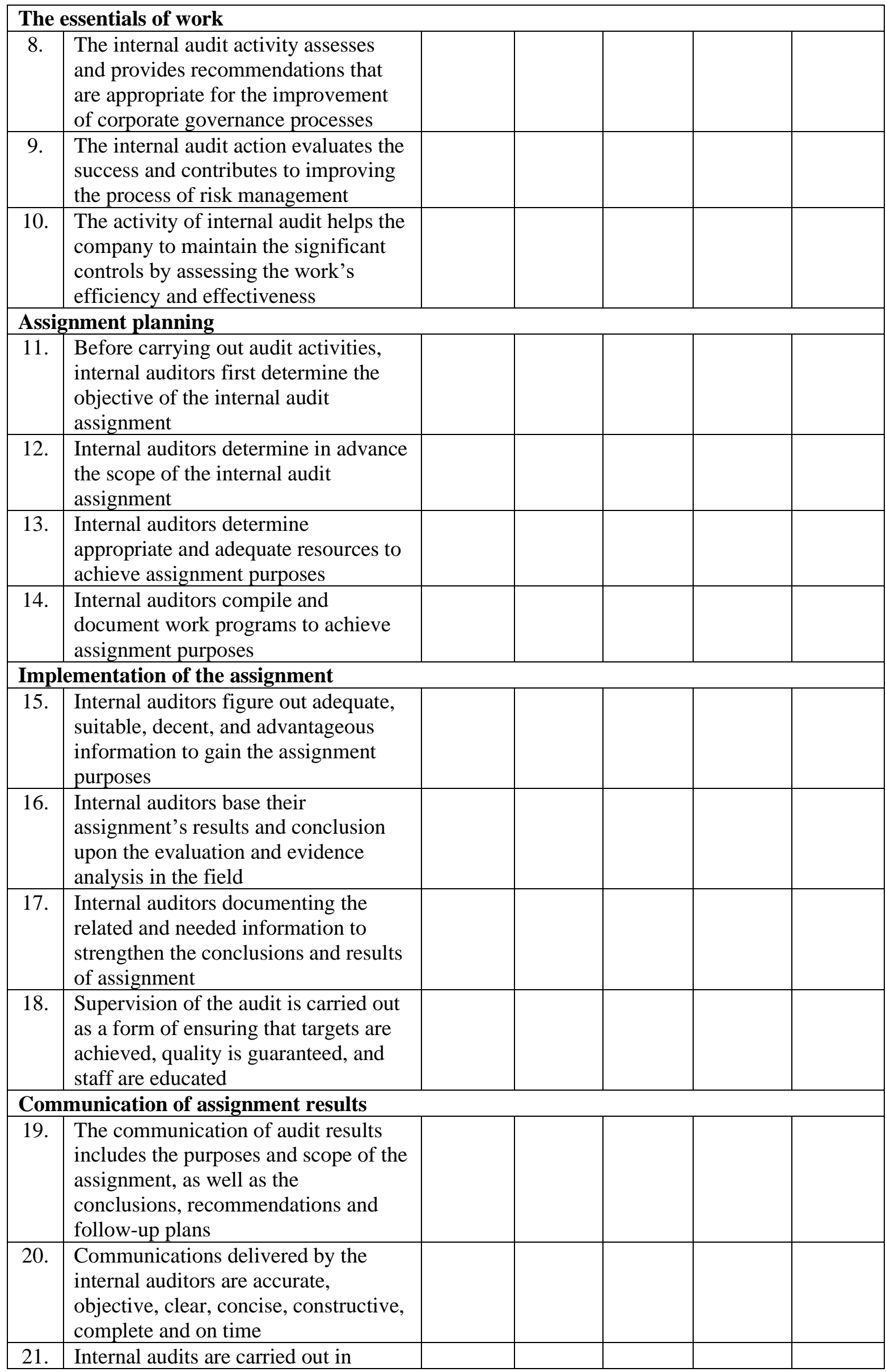




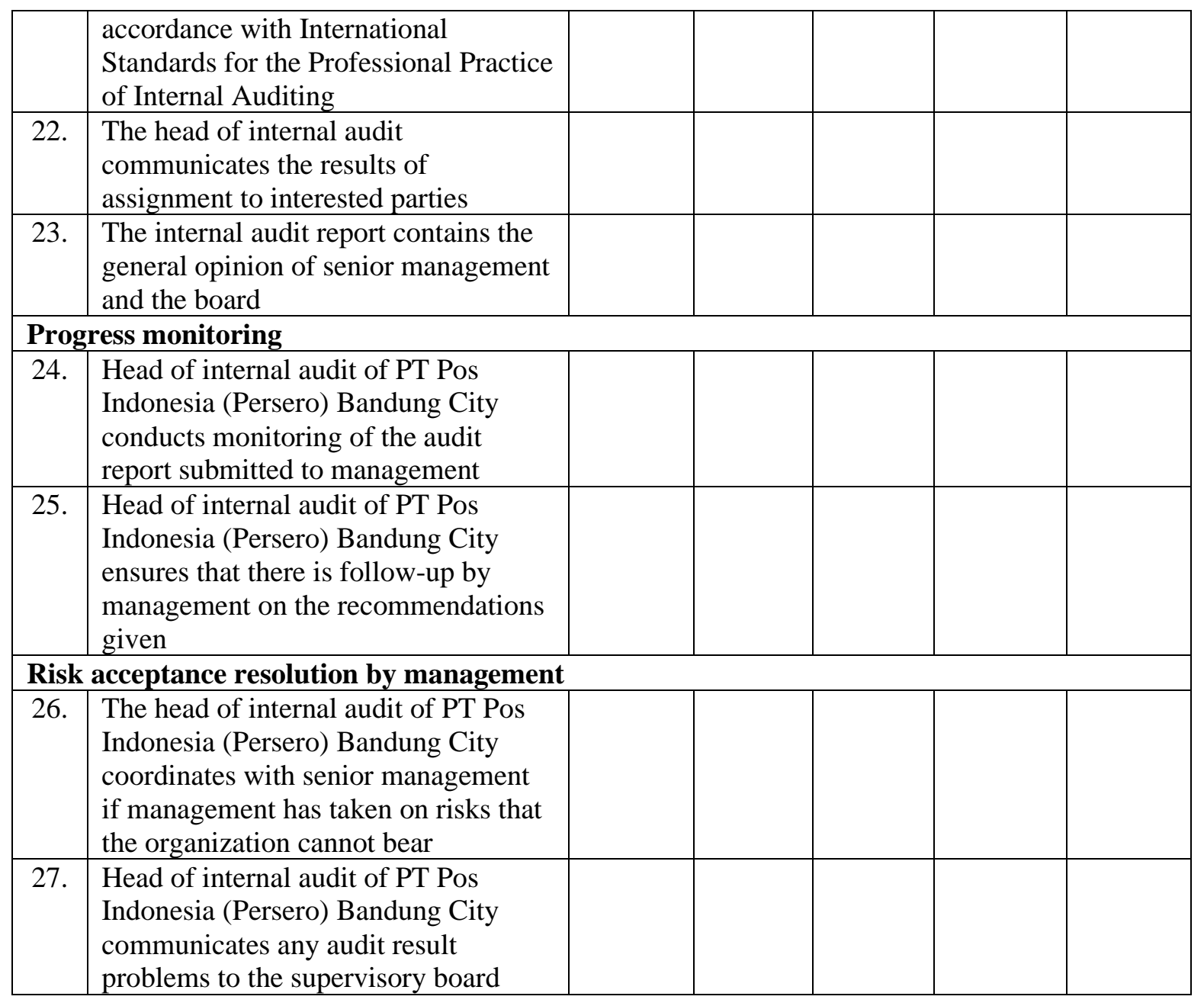

Table 3. Internal control variable questionnaire (X2)

\begin{tabular}{|l|l|l|l|l|l|l|}
\hline \multirow{2}{*}{ No } & \multicolumn{1}{|c|}{ Questions } & \multicolumn{5}{c|}{ Alternative answers } \\
\cline { 2 - 6 } & Control environment & & & & \\
\hline 1. & $\begin{array}{l}\text { PT Pos Indonesia (Persero) Bandung } \\
\text { City upholds integrity and ethical } \\
\text { values in carrying out its activities }\end{array}$ & & & & & \\
\hline 2. & $\begin{array}{l}\text { Employees at PT Pos Indonesia } \\
\text { (Persero) Bandung City have } \\
\text { sufficient competence according to } \\
\text { their educational background }\end{array}$ & & & & & \\
\hline 3. & $\begin{array}{l}\text { The leadership style shown by the } \\
\text { leadership at PT Pos Indonesia } \\
\text { (Persero) Bandung City is quite wise } \\
\text { in relation to decision making. }\end{array}$ & & & & & \\
\hline 4. & $\begin{array}{l}\text { The organizational structure at PT Pos } \\
\text { Indonesia (Persero) Bandung City is } \\
\text { sufficient and clear }\end{array}$ & & & & & \\
\hline 5. & $\begin{array}{l}\text { PT Pos Indonesia (Persero) Bandung } \\
\text { City has the policy to improve the } \\
\text { quality of employee resources }\end{array}$ & & & & & \\
\hline Risk assessment & & & & & \\
\hline 6. & PT Pos Indonesia (Persero) Bandung & & & & & \\
\hline
\end{tabular}




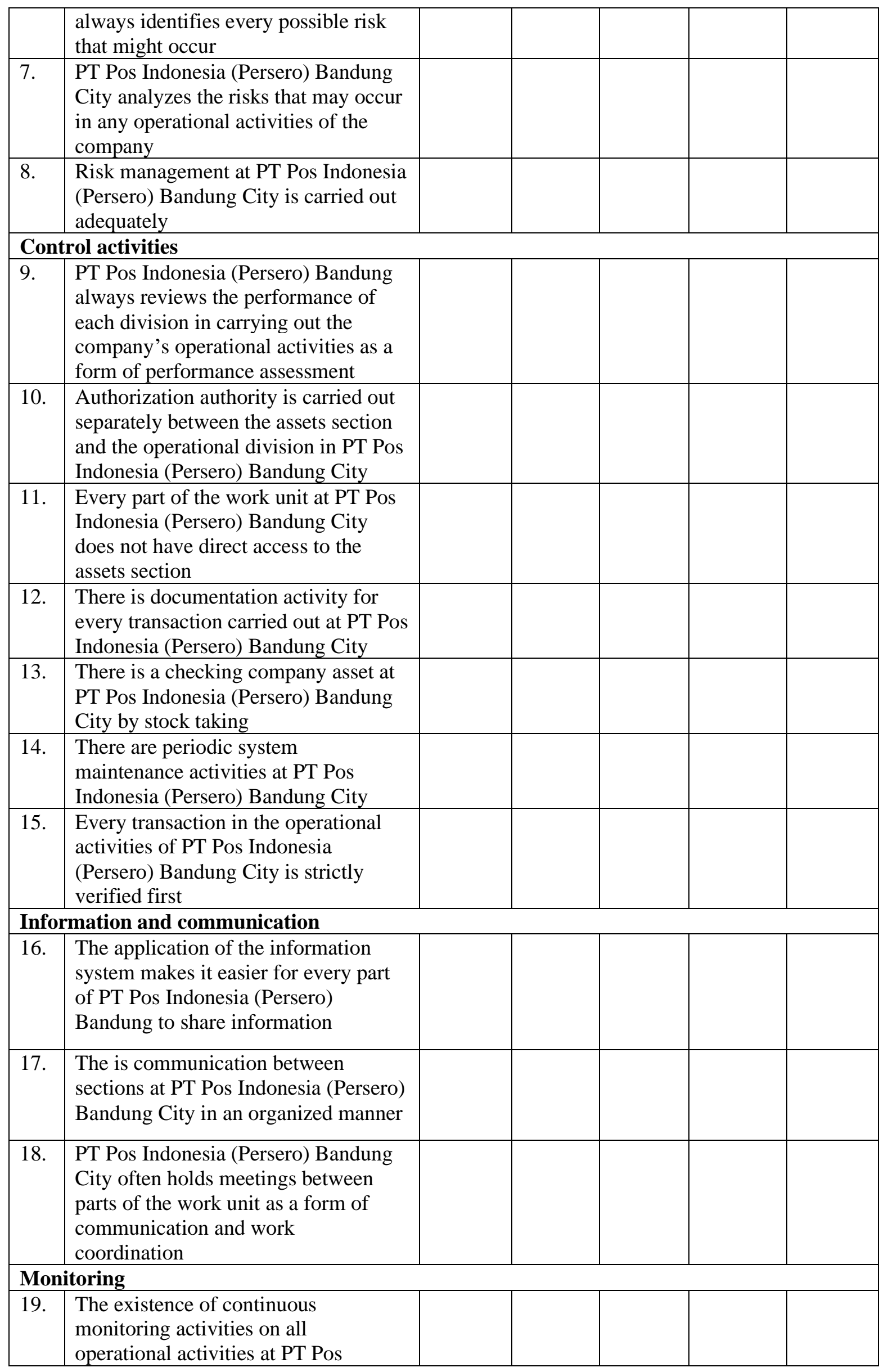




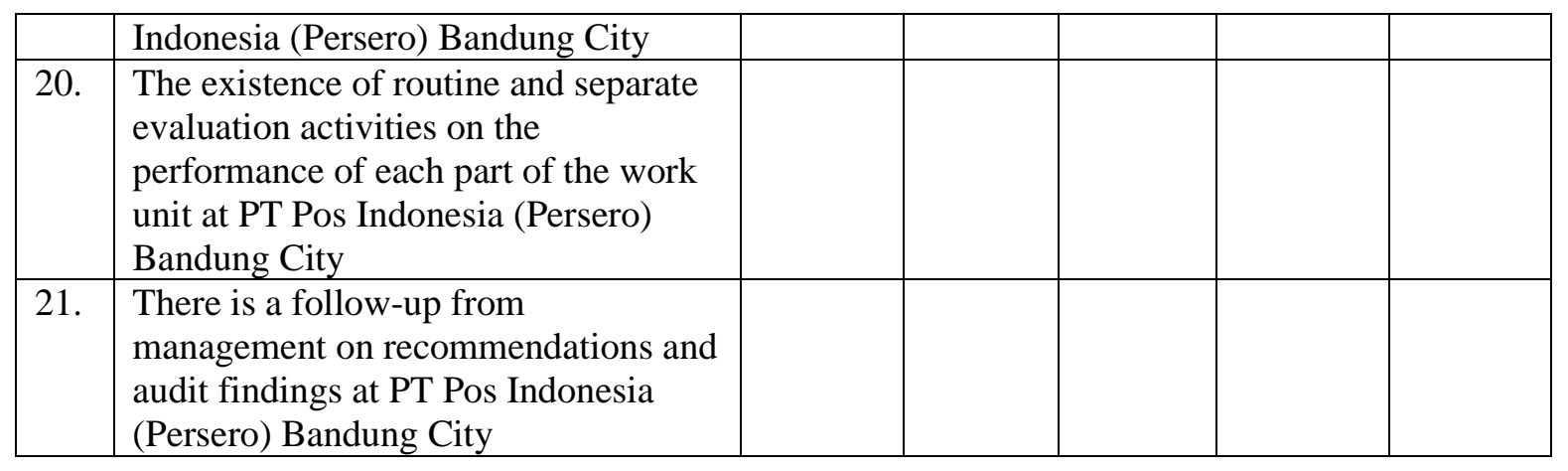

Table 4. Fraud prevention variable questionnaire (X2)

\begin{tabular}{|c|c|c|c|c|c|c|}
\hline \multirow{2}{*}{ No } & \multirow{2}{*}{ Questions } & \multicolumn{5}{|c|}{ Alternative answers } \\
\hline & & SA & $\mathbf{A}$ & QA & D & SD \\
\hline \multicolumn{7}{|c|}{ Building a good internal control structure } \\
\hline 1. & $\begin{array}{l}\text { The creation of a good organizational } \\
\text { culture and increasing awareness of } \\
\text { control of employees at PT. Pos } \\
\text { Indonesia (Persero) Bandung City }\end{array}$ & & & & & \\
\hline 2. & $\begin{array}{l}\text { Internal examiners always identify, } \\
\text { analyze and manage various risks that } \\
\text { may occur in PT Pos Indonesia } \\
\text { (Persero) Bandung City }\end{array}$ & & & & & \\
\hline 3. & $\begin{array}{l}\text { There is a clear standard operating } \\
\text { procedure and a transaction } \\
\text { authorization policy carried out only } \\
\text { by people who have the authority at } \\
\text { PT Pos Indonesia (Persero) Bandung } \\
\text { City }\end{array}$ & & & & & \\
\hline 4. & $\begin{array}{l}\text { Information and communication } \\
\text { systems make it easier for every part } \\
\text { of PT Pos Indonesia (Persero) } \\
\text { Bandung to obtain and share the } \\
\text { information needed to manage, } \\
\text { implement and control operational } \\
\text { activities. }\end{array}$ & & & & & \\
\hline 5. & $\begin{array}{l}\text { The existence of monitoring and } \\
\text { inspection activities on all operational } \\
\text { activities at PT Pos Indonesia } \\
\text { (Persero) Bandung City on an ongoing } \\
\text { basis }\end{array}$ & & & & & \\
\hline \multicolumn{7}{|c|}{ Making control activities more effective } \\
\hline 6. & $\begin{array}{l}\text { There is an activity reviewing the } \\
\text { performance of employees of PT Pos } \\
\text { Indonesia (Persero) Bandung City as a } \\
\text { whole as a form of evaluation }\end{array}$ & & & & & \\
\hline 7. & $\begin{array}{l}\text { Information processing at PT Pos } \\
\text { Indonesia (Persero) Bandung City is } \\
\text { carried out in order to produce } \\
\text { accurate and complete information }\end{array}$ & & & & & \\
\hline 8. & $\begin{array}{l}\text { There are restrictions on access to part } \\
\text { of the assets for employees who do } \\
\text { not have authority }\end{array}$ & & & & & \\
\hline 9. & The separation of the functions of & & & & & \\
\hline
\end{tabular}




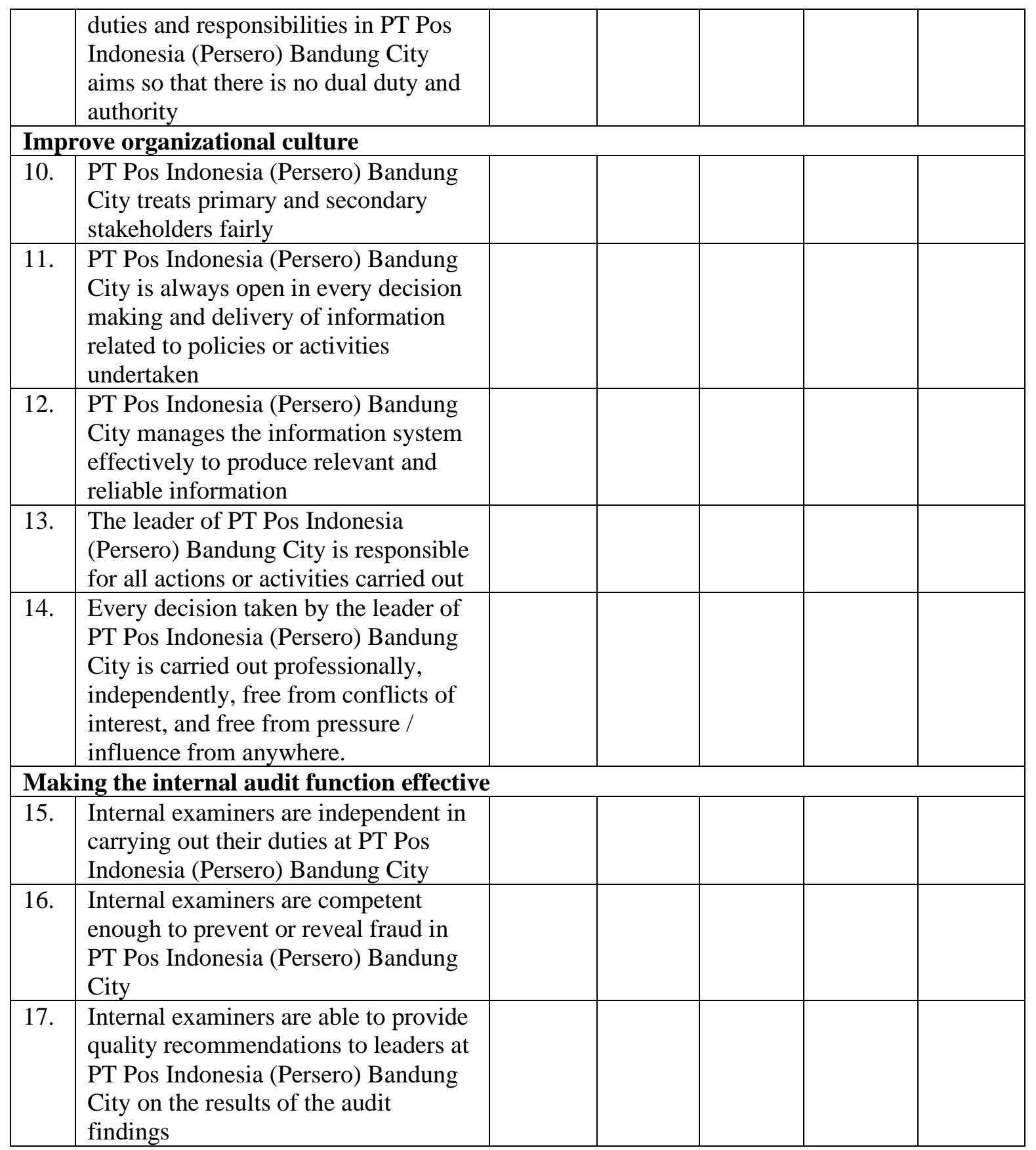

\subsection{Validity test}

Validity is a measuring tool used to obtain data. The result of the study is valid if both of the data collected and the data that occurs of the study have a similarity. (Sugiyono, 2017: 348). Validity can be measured using the product moments Pearson correlation coefficient. According to Sugiyono (2017: 348$)$ the formula for the correlation coefficient for product moments Pearson is as follows:

Information:

$$
\mathrm{r}=\frac{\mathrm{n} \sum \mathrm{XY}-\sum \mathrm{X} \sum \mathrm{Y}}{\sqrt{\left(\mathrm{n} \sum \mathrm{X}^{2}-\left(\sum \mathrm{X}\right)^{2}\right) \times\left(\mathrm{n} \sum \mathrm{Y}^{2}-\left(\sum \mathrm{Y}\right)^{2}\right)}}
$$

$\mathrm{r}=$ correlation coefficient

$\mathrm{n}=$ Total of respondents

$\mathrm{Y}=$ The sum total score of all Yi items

$\mathrm{X}=$ Total score of each item $\mathrm{Xi}$ 
In this study, the item validity was measured by comparing the calculated $r$ value and $r$ table; that is, the calculated $r$ value was obtained from the results in the correlated item-total correlation column. If the calculated $r$ value $>r$ table, then the item or question or indicator is declared valid (Ghozali, 2016: $\underline{53)}$.

\subsection{Reliability test}

Reliability test is done by doing equivalent, test-retest (stability), and a combination of both. Internally, Analyzing the consistency of the items on the instrument with specific techniques is the way to test the reliability of the instrument. The researcher can carry reliability testing with the Cronbach alpha technique for interval/essay data types (Sugiyono 2017: 356). According to Sugiyono (2017: 356$)$ the formula for calculating Cronbach's alpha is as follows:

$$
\text { Alpha }(\alpha)=\frac{\mathrm{k} \cdot \overline{\mathrm{r}}}{1+(\mathrm{k}-1) \overline{\mathrm{r}}}
$$

Information:

$$
\text { (Sugiyono, 2017:356) }
$$

$\mathrm{k}=$ The number of manifest variables that make up the latent variable

$\bar{r}=$ Average correlation between manifest variables

Questionnaire items are said to be reliable (feasible) if Cronbach's alpha based on standardized items> 0.70 (Ghozali, 2016: 53).

\section{Results and discussions}

\subsection{Results}

Table 5. Analysis of Multiple Linear Regression

\section{Source: SPSS Output 25}

\begin{tabular}{|l|r|}
\hline \multicolumn{1}{|c|}{ Variable } & Coefficient \\
\hline (Constant) & 0,287 \\
\hline Internal Audit & 0,417 \\
\hline Internal Control & 0,503 \\
\hline
\end{tabular}

Based on table 5 above shows that the regression equation model formed based on the results of the study are as follows:

$$
Y=0,287+0,417 X_{1}+0,503 X_{1}+e
$$

The equation above shows that internal audit and internal control have a positive direction of influence, meaning that the internal audit and control and the prevention of fraud are higher, and vice versa.

Table 6. Partial hypothesis testing

Source: SPSS Output 25

\begin{tabular}{|l|c|c|c|}
\hline \multicolumn{1}{|c|}{ Variable } & t Value & Probability Value & Result \\
\hline Internal Audit & $5,469>1,987$ & $0,000<0,05$ & $\mathrm{H}_{1}$ Accepted \\
\hline Internal Control & $6,674>1,987$ & $0,000<0,05$ & $\mathrm{H}_{2}$ Accepted \\
\hline
\end{tabular}

Based on table 6 above partially shows that internal audit and internal control affect the prevention of fraud.

Table 7. Simultaneous hypothesis testing

Source: Output result Eviews 9

\begin{tabular}{|c|c|c|c|}
\hline Variable & F Value & Probability Value & Result \\
\hline $\begin{array}{c}\text { Internal Audit and Internal } \\
\text { Control }\end{array}$ & $96,907>3,10$ & $0,000<0,05$ & Accepted \\
\hline
\end{tabular}


Based on table 7 above simultaneously shows that internal audit and internal control affect the prevention of fraud.

Table 8. Simultaneous determination coefficient testing

Source: SPSS Output 25

\begin{tabular}{|c|c|c|}
\hline Variable & R-squared & Percentage \\
\hline Internal Adit and Internal Control & 0,688 & $68,8 \%$ \\
\hline
\end{tabular}

Based on table 8 above shows that the magnitude of the influence of internal audit and internal control in contributing influence to the prevention of fraud of $68.8 \%$.

Table 9. Partial determination coefficient testing

Source: SPSS Output 25

\begin{tabular}{|l|c|c|c|}
\hline \multicolumn{1}{|c|}{ Variable } & R-squared & Percentage & Result \\
\hline Internal Audit & 0,302 & $30,2 \%$ & $\mathrm{H}_{1}$ Accepted \\
\hline Internal Control & 0,386 & $38,6 \%$ & $\mathrm{H}_{2}$ Accepted \\
\hline
\end{tabular}

Table 9 above shows that the influence of internal audits on fraud prevention is $30.2 \%$. Besides, the influence of internal control on fraud prevention was $38.6 \%$.

\subsection{Discussions}

The research results on internal audit show that the total actual score is 8795 , the ideal score is 12285 , the percentage value is $71.59 \%$ and the mean score is 3.58 , which is in the good category. This shows that the implementation of internal audit indicated by PT Pos Indonesia (Persero) Bandung is included in the good category.

The research results on fraud prevention show the total value of the actual score of 5248, the ideal score of 7735 , the percentage value of $67.85 \%$ and the mean score of 3.39 which are categorized as quite good. This shows that the fraud prevention of PT Pos Indonesia (Persero) Bandung is in the fairly good category.

The results showed that the internal audit influences fraud prevention. The amount of influence of internal audit in contributing to the effect of fraud prevention is $30.2 \%$. The theoretical basis supports this study's results in the previous discussion, which states that one way to prevent and minimize fraud is to increase internal audit implementation. The internal audit aims to help organizations to have implemented adequate controls. Moreover, it can be done by evaluating effectiveness and efficiency and encouraging continuous improvement. (Sawyer et al., 2014: 55). Internal auditors are the most appropriate agents to realize internal control, risk management, and good corporate governance, which will add value to resources and the company (Kumaat, 2014: 35).

\section{Conclusion}

The results show that internal audit affects fraud prevention. The amount of influence of internal audit in contributing influence to the prevention of fraud of $30.2 \%$. The theoretical basis supports the results of this study in the previous discussion, which states that one way to prevent and minimize fraud is to improve internal audit implementation. Internal audits aim to implement adequate controls by checking their efficiency and effectiveness and encourage continuous improvement. (Sawyer et al., 2014:55). Internal auditors as the most appropriate agent to realize internal control, risk management and good corporate governance, which will undoubtedly add value to resources and the company (Kumaat, 2014:35).

Risks faced by the company include integrity risk, namely the risk of fraud by management or company employees, illegal actions, or other irregularities that can reduce the good name/reputation of the company in the business world or reduce the company's ability to maintain internal audit. It actually is a straight belief, separated activity and consultation purposed to give value and boost 
organizational activities. This internal audit aims to achieve its goals by taking a systematic and disciplined approach to check and lift the effectiveness of risk management, control, and governance processes. (Redding et al., 2013:2). Internal auditors help to prevent and minimize fraud by testing the effectiveness and adequacy of the internal control system by evaluating the extent of potential risks to be identified. (KOPAI, 2004:65). The existence of these risks requires internal auditors to develop preventive measures that can minimize fraud (Amrizal, 2014:11). This study's results are in parallel with the results of previous studies by Maliawan et al. (2017), Suginam (2017), Wijaya and Nugraha (2017), Gusnardi (2011), Festi (2014), Monisola (2013), Ait Novatiani and Julaeha (2013). The results of his research indicate that internal audit affects fraud prevention.

The results also show that internal control affects the prevention of fraud. The amount of influence of internal control in contributing influence to the prevention of fraud of $38.6 \%$. The theoretical basis supports this study's results in the previous discussion, which states that in order for the company objectives set by top management to be achieved, the security of company assets is guaranteed and operations can be carried out efficiently and effectively. Moreover, it also needs to make an effective and well-structured internal control to prevent fraud (Priantara, 2013: 196). The primary way to prevent fraud is by making an internal control system in the organization's activities. Internal control to effectively prevent fraud must be in a decent design of its control structure and sound simple in its application. (Karyono, 2013: 47). The relationship between internal control and fraud problems in a company is very related. Fraud is always a difficult issue. A good internal control system aims to ensure that organizational activities are effective and efficient (Tugiman, 2014: 12). A comprehensive internal control system implemented thoroughly and regularly monitoring the activities of an organization is an important step to safeguard and detect the risk of losses caused by fraud in the financial sector. Internal control is very important in detecting financial fraud that is at the risk of harming the company (Susanto, 2014: 93).

Implementation of internal control can at least reduce management collusion regarding fraud (Natasya et al., 2017). Fraud prevention strategies are related to controlling the drivers of fraud by creating conditions that can encourage fraud prevention efforts, so to implement this strategy, internal control must be implemented effectively. Good internal control is a widely used method by many parties to prevent fraud. It can be said that more appropriate the application of internal control, the prevention of fraud in the organization will increase (Wulandari and Nuryatno, 2018). This study's results are in parallel with the results of previous studies by Maliawan et al. (2017), Suginam (2017), Wijaya and Nugraha (2017), Gusnardi (2011), Zarlis (2018), Saleh (2016). The results of his research indicate that internal control influences the prevention of fraud.

The following conclusions are obtained based on the results and discussions:

1. The research results on internal audit showed that the implementation of internal audit shown by PT Pos Indonesia (Persero) Bandung was included in both categories.

2. The implementation of internal control shown by PT Pos Indonesia (Persero) Bandung is included in the quite good category. Fraud prevention of PT Pos Indonesia (Persero) Bandung is categorized quite good.

3. This study's result also showed that internal audit and internal control influence fraud prevention. The higher the application of internal audit and internal control, the higher the prevention of fraud.

\section{Acknowledgement}

The author would like to thank Bunga Indah Bayunitri, S.E., M.M., Ak., C.A., who initiated and gave thought input to the author in conducting this research. In addition, the authors thank Universitas Widyatama Bandung for giving us a platform to explore our knowledge in accounting, auditing, and internal auditing. 


\section{References}

Agoes, Sukrisno. (2017). Auditing. Petunjuk praktis pemeriksaan akuntan oleh akuntan publik. Jakarta: Salemba Empat.

Ait, R. Novatiani and Eha Julaeha. (2013). Internal audit influence to fraud prevention. Widyatama University, Economics Faculty-Bandung, Indonesia.

Amrizal. (2014). Analisis kritis pelanggaran kode etik profesi akuntan publik di indonesia. Jurnal Liquidity, 3(1).

Arens, A. A., Randal, J. E., \& Mark, S. B. (2014). Auditing dan jasa assurance (terjemahan). Edisi ke lima belas. Jakarta: Erlangga.

Association of Certified Fraud Examiners (ACFE). (2017). Survey fraud indonesia 2016. Penerbit : ACFE Indonesian Chapter.

Festi, Theresa T. (2014). Pengaruh peran audit internal terhadap pencegahan kecurangan. JOM FEKON, 1(2).

Ghozali, I. (2016). Aplikasi analisis multivariate dengan program IBM SPSS 23. Semarang: BPFE Universitas Diponegoro.

Gusnardi. (2011). Pengaruh peran komite audit, pengendalian internal, audit internal dan pelaksanaan tata kelola perusahaan terhadap pencegahan kecurangan. Ekuitas, 15 (1), 130 - 146. ISSN 1411-0393. Fakultas Ekonomi. Universitas Riau.

Karyono. (2013). Forensic fraud. Yogyakarta: CV. Andi.

Konsorsium Organisasi Profesi Audit Internal. (2004). Standar profesi audit internal. Jakarta: Yayasan Pendidikan Internal.

Kumaat, Valery G. (2011). Internal audit. Jakarta: Erlangga.

Maliawan, Ida Bagus Dwika., Edy Sujana, dan I Putu Gede Diatmika. (2017). Pengaruh audit internal dan efektivitas pengendalian interen terhadap pencegahan kecurangan (fraud). e-Journal S1 Ak Universitas Pendidikan Ganesha, 8(2).

Monisola, Olowolaju. (2013). Effect of internal audit on prevention of frauds, errors and irregularities in corporate organisation. Research Journal of Finance and Accounting. ISSN 2222-1697 (Paper) ISSN 2222-2847 (Online),4(19). Retrieved from www.iiste.org.

Movanita, Ambaranie Nadia Kemala. (2017). Diduga ada penyimpangan pembagi bonus, pt pos dilaporkan ke kejaksaan. Dikutip dari artikel: https://nasional.kompas.com/read/2017/12/12/10233911/diduga-ada-penyimpanganpembagian-bonus-pt-pos-dilaporkan-ke-kejaksaan.

Natasya, Toisuta Novenia., Herman Karamoy., dan Robert Lambey. (2017). Pengaruh komitmen organisasi dan pengendalian internal terhadap resiko terjadinya kecurangan (fraud). Jurnal Riset Akuntansi Going Concern 12 (2), 847-856.

Priantara, Diaz. (2013). Fraud auditing \& investigation. Jakarta: Mitra Wancana Media.

Rahman, Ainur. (2016). Mengungkap borok korupsi PT Pos Indonesia. Dikutip dari artikel: www.gresnews.com/berita/hukum/108710-mengungkap-borok-korupsi-pt-pos-indonesia/

Redding, Kurt, F, Paul J. Sobel, dan Michael J. Head. (2013). Internal auditing: assurance \& advisory services. Third Edition. Unites Stated Of America: The Institute of Internal Auditors Research Foundation (IIARF).

Saleh, Mohammed. (2016). Effect of internal control on fraud prevention of the listed manufacturing industries in Nigeria. International Journal of Business and Management, 12(2). ISSN 17333550 E-ISSN 1833-8009.

Sawyer, Lawrence B, Dittenhofer Mortimer A, dan Scheiner James H. (2014). Internal auditing. Diterjemahkan oleh: Desi Adhariani. Jakarta: Salemba Empat.

Suginam. (2017). Pengaruh peran audit internal dan pengendalian intern terhadap pencegahan fraud. Riset \& Jurnal Akuntansi, 1(1) e - ISSN : 2548 - 9224. p - ISSN : 2548 - 7507.

Sugiyono. (2017). Metode penelitian kuantitatif, kualitatif, dan R\&D. Bandung : Alfabeta, CV.

Susanto, Azhar. (2014). Sistem informasi akuntansi. Bandung: Lingga Jaya.

Tugiman, Hiro. (2014). Standar profesional audit internal. Yogyakarta: Kanisius.

Wijaya, Minadi dan Ginanjar Adi nugraha. (2017). Pengaruh pengendalian intern dan audit intern terhadap fraud. Majalah Ilmiah Manajemen dan Bisnis, 14(1). ISSN : 1411 - 1977.

Wulandari, Dewi Novita dan Muhammad Nuryatno. (2018). Pengaruh pengendalian internal, kesadaran anti-fraud, integritas, independensi, dan profesionalisme terhadap pencegahan 
kecurangan. JRAMB, Prodi Akuntansi, Fakultas Ekonomi, UMB Yogyakarta, 4 (2). ISSN : 2460-1233.

Zarlis, Dwi. Pengaruh pengendalian internal terhadap pencegahan fraud di rumah sakit. Jurnal Transparansi, 1(2), 206-217. E-ISSN 2622-0253 